Fiscal Studies (1992) vol. 13 no. 3 pp. 1-14

\title{
Public Debt and Pension Policy
}

\author{
LANS BOVENBERG* and CAREL PETERSEN ${ }^{\dagger}$
}

\section{INTRODUCTION}

Indicators of the sustainability of fiscal policies play an important role in the conduct of the international surveillance of fiscal policies. The construction of these indicators, however, is beset with serious problems. To illustrate, many authors have observed that conventional measures of public debt are potentially misleading indicators of public wealth and the effects of fiscal policy on the intergenerational distribution of resources (see, for example, Blejer and Cheasty (1991) and Blanchard et al. (1990)). In particular, policies that do not directly result in an increase in public debt may yield similar effects to the accumulation of public debt in that they impose long-term budgetary costs and require an increase in tax rates or a cut in spending in the future. Examples of these policies include selling public assets, reducing public investments and public loans, and introducing unfunded public pensions. Indicators of fiscal sustainability should measure the long-run costs of these policies in order to avoid unsustainable fiscal policies that erode the stock of public wealth.

Most studies that attempt to construct internationally comparable indicators of fiscal sustainability focus on forecasting government spending. The OECD and the IMF, for example, have examined how ageing would affect spending on social security pensions and health care into the next century (see, for example, Heller, Hemming and Konhert (1986) and Hagemann and Nicoletti (1989)). In this paper we focus on two issues that the literature on fiscal sustainability has largely ignored. The first issue concerns the way governments finance social security old-age pensions and the pensions of their own employees (Section II). The second issue involves the relationship between, on the one hand, supplementary pension saving and, on the other hand, future revenues from the personal income tax (Section III).

\footnotetext{
* Center for Economic Research, Tilburg University and Research Center for Economic Policy, Erasmus University Rotterdam.

$\boldsymbol{t}$ Department of Public Administration, University of Twente and Petersen Consult.

The authors would like to thank Jean Frijns, Fred Krapels, Rob Mulder and an anonymous referee for helpful comments on an earlier draft.
} 
In particular, the present tax treatment of supplementary pensions and life assurance implies that countries with substantial savings in pension and life assurance funds can anticipate a broader base of the personal income tax compared with countries with less pension savings. Section IV explores two alternative tax treatments of pension saving with different implications for public debt.

\section{SOCIAL SECURITY PENSIONS AND SUPPLEMENTARY PENSIONS OF PUBLIC SERVANTS}

Governments differ in how they make provisions for their explicit or implicit obligations associated with social security old-age pensions and the supplementary pensions of their employees. Many governments finance these pensions out of current revenues on a pay-as-you-go basis. Others, in contrast, accumulate capital to provide for these pensions. In particular, Sweden, Japan and Canada effectively pre-fund part of their social security old-age pensions. These countries have accumulated substantial funds in their public pension plans; in 1989 social security reserves amounted to 30 per cent of GDP in Sweden, 18 per cent of GDP in Japan and 8 per cent of GDP in Canada (see, for example, Munnell and Ernsberger (1989)). Although in Japan the pay-as-you-go component has gained importance in recent years, capital has continued to accumulate in the social security funds. Also the United States is currently building up significant reserves in its social security trust fund in order to ease the future burden of public pension benefits.

As regards the supplementary pensions of public employees, the Dutch Government contracts out almost all its obligations to the public sector pension fund (Algemeen Burgelijk Pensioenfonds (ABP)), which fully funds the pensions of the employees in the public sector. Also the Swiss Government and local authorities in the United States and the United Kingdom fund the pensions of their employees.

In principle, the unfunded explicit or implicit pension liabilities of the various governments should be added to the stocks of public debt to arrive at a better measure for the liabilities of the public sector. ${ }^{1}$ Unfortunately, measures for the unfunded pension liabilities of the various governments are difficult to come by. Lacking this information, we adopt a 'second-best' procedure. In particular, we make the international data on public debt more comparable by subtracting from public debt the assets in both social security trust funds and the pension funds for public employees (Table 1). An international comparison of this nature fails to capture international differences in future pension liabilities (as a percentage of GDP). Hence, it overstates the relative wealth position of governments that feature large (implicit or explicit) pension commitments to their employees.

\footnotetext{
' Future pension benefits are not contractual obligations in the same way as regular debt instruments are and feature distinct risk characteristics. Hence, these two types of liability are not perfectly substitutable (see also Section IV). One can therefore argue that, rather than adding the pension liabilities to their regular debt, governments should provide supplemental information regarding the potential future liabilities on account of the pensions payments to their own employees and social security old-age pensions.
} 
TABLE 1

Public Debt and Assets in Funded Pension Schemes of the Government Sector in Selected OECD Countries, 1989

Percentage of GDP

\begin{tabular}{l|cccc}
\hline & $\begin{array}{c}\text { Pension } \\
\text { funds of } \\
\text { public } \\
\text { employees }\end{array}$ & $\begin{array}{c}\text { Social security } \\
\text { funds }\end{array}$ & $\begin{array}{c}\text { Gross } \\
\text { public } \\
\text { debt }\end{array}$ & $\begin{array}{c}\text { Public debt } \\
\text { adjusted for } \\
\text { public pension } \\
\text { schemes }\end{array}$ \\
\hline United States & $17^{\mathrm{b}}$ & 3 & 54 & 34 \\
Japan & $12^{\mathrm{b}}$ & 18 & 69 & 39 \\
United Kingdom & 18 & 0 & 39 & 21 \\
Netherlands & 34 & 0 & 81 & 47 \\
Germany & 0 & 0 & 43 & 43 \\
France & 0 & 0 & 47 & 47 \\
\hline
\end{tabular}

${ }^{a}$ As defined in OECD, Economic Outlook, December 1990.

${ }^{b}$ Estimate based on the growth of the assets from previous years.

Source: US: Employee Benefit Research Institute (EBRI), Issue Brief, July 1988 and Social Security Bulletin, July 1990; Japan: Insurance News; UK: PDFM, Pension Fund Indicators, May 1990; Netherlands: van Loo, 1990.

The correction for the funding of public pension commitments causes public debt in Japan and the United States to fall below that in France and Germany. The adjusted level of public debt in the Netherlands falls to a level comparable to that in France and Germany. However, this information should not necessarily be interpreted as indicating that the public finances in these countries are in order. Not only data on public debt, but also the dynamics of the financial deficit of the public sector, can reveal important information about the health of the public finances. In particular, governments that fund the pensions of their employees can achieve short-term budgetary gains at the expense of higher long-run budgetary costs by reducing contributions to the pension schemes of public employees. In the Netherlands, for example, a substantial part of the decline of the public sector deficit in recent years has been achieved through a reduction in the financial surplus (i.e. the difference between receipts of the pension fund - the sum of capital income from capital assets and collected pension contributions - and benefits paid out) of the pension scheme for public employees.

\section{TAX CLAIMS ON FUNDED PENSION AND LIFE ASSURANCE SCHEMES}

Another important aspect of the international comparability of public debt data concerns the interaction between the tax treatment of supplementary pensions and the size of funded pension and life assurance schemes. 


\section{Tax Treatment of Supplementary Pensions}

In most countries, supplementary pensions are taxed on a consumption-tax basis ${ }^{2}$ by allowing pension premiums to be deducted from the income tax liability while subjecting the pension benefit to tax. The provisions of the OECD Model Tax Treaty that deal with the tax treatment of the benefits from private pension schemes are consistent with this tax treatment. According to these provisions, the country where a retiree resides should collect income tax on pension benefits. This 'cash-flow' treatment implies that taxes are deferred until retirement. An alternative version of the consumption tax is the so-called 'prepayment method'. According to this method, premiums are not tax-deductible — but neither the returns on the pension assets nor the pension benefits are included in the tax net. In essence, consumption taxes are 'prepaid' during the working life. The two distinct tax systems could be interpreted as implying two distinct tax bases. Under the prepayment system, labour income is the tax base. If benefits are consumed, consumption constitutes the base for the cash-flow tax.

The two alternative tax systems may affect the timing of tax collection. In a pay-as-you-go pension system, pension saving is zero and premiums always equal benefits. Accordingly, the two versions of the consumption tax yield the same revenue at each moment as long as the average tax rate at which premiums are deducted is equal to the average tax rate at which benefits are taxed. In a funded system, however, the two taxes raise revenue at different points in time. The prepayment system collects taxes earliest. Compared with the situation under the prepayment system, under the cash-flow system the government in effect provides a loan to the private sector, thereby enlarging its financial deficit. At the same time, private individuals need to save more under the cash-flow system in order to meet future income tax payments on their pension benefits (i.e. to pay back the implicit loan extended by the government) while maintaining their after-tax pension benefits. Therefore, if private agents anticipate future tax payments, private pension saving should in effect replace part of public saving. The substitution of private for public saving looks like Ricardian equivalence, even though households do not have to be altruistic towards their heirs. The reason is that the future taxes corresponding to the higher stock of public debt are not shifted to future generations but are expected to be paid by currently living generations during retirement.

It could be argued that one should attribute part of private saving under the cash-flow system to public saving because part of private pension saving corresponds to future income taxes on pension benefits. To judge the effect of a given budget deficit on the sustainability of fiscal policy, one has to keep in mind that high rates of pension saving may widen the financial deficit of the public sector but that the government at the same time accumulates an implicit claim on private pension funds. The cash-flow tax reduces the income tax base during the transitional

\footnotetext{
${ }^{2}$ Strictly speaking, pensions are taxed on a consumption-tax basis only if benefits are consumed.
} 
period when pension funds are built up, for example when the baby boom generation participates in the labour force or when private pension schemes are accumulated after privatisation. After the pension funds have matured, however, pension benefits exceed pension premiums and the tax base is broader, and the primary deficit smaller, than under the prepayment method, at least if the economy is dynamically efficient, i.e. as long as the rate of return on the capital in the pension fund exceeds the growth rate of the economy (see, for example, Abel et al. (1989)). However, the cash-flow tax yields the largest financial deficit of the public sector in the steady state as long as pension saving remains positive and pension funds therefore grow, for example on account of growth in national income. Although the cash-flow tax yields the broadest tax base in the steady state, it nevertheless produces the largest financial deficit because the additional interest expenses on the larger stock of public debt exceed the additional tax revenue.

Most industrial countries adopt the cash-flow system. ${ }^{3}$ This implies that the governments in these countries have acquired an implicit tax claim on funded pension schemes, which can be computed as the product of the average income tax rate on pension benefits and the assets of pension funds. These tax claims should be taken into account when using data on public debt to compare fiscal sustainability across countries. The governments of these countries are less vulnerable to changes in interest rates than they appear on the basis of their stocks of public debt. Whereas higher interest rates raise the cost of servicing public debt, they also increase the return on the implicit tax claim on pension funds. Governments benefit the most if pension funds use windfalls to reduce pension premiums because these premiums are typically deducted at rather high marginal tax rates. If windfalls are used to improve future pension benefits, the government benefits through a higher value of the tax claim on the private pension assets. In this case, the cash flow of the government improves only in the long run when higher pension benefits yield larger tax revenues.

\section{The Interpretation of the Data on Tax Claims}

Before presenting the estimates for the tax claims and the adjustments to public debt, we emphasise at the outset that our correction to the data on public debt needs to be interpreted with caution for a number of reasons. Most importantly, the correction performed here singles out only one of a number of possible corrections to regular public debt data. Therefore, the data provided here need to be supplemented by more information in order to arrive at reliable internationally comparable indicators of public wealth. On the tax side, we have considered only the tax claims on account of deferred personal income tax. In principle, one could also measure the tax claim

\footnotetext{
${ }^{3}$ Some countries, such as Australia, New Zealand, Denmark, Sweden and Belgium, do not really tax pension saving on a consumption-tax basis because they collect tax also on (part of) the retums of pension funds.
} 
on capital assets, including those in pension funds, on account of indirect consumption taxes, such as excises, environmental levies and VAT. Besides these tax claims, other implicit tax claims exist, for example dividend taxes on capital accumulated within firms and capital gains taxes on selected capital assets.

Against these tax claims on the private sector, the private sector holds implicit claims on the public sector, in the form of various types of implicit and explicit public expenditure commitments. These claims are especially large in ageing societies, ${ }^{4}$ elaborate welfare states with extensive subsidy schemes (for example, in housing and public transport) and social security programmes, and countries with large environmental 'debts'.. The indicators of fiscal sustainability developed by the OECD (see, for example, Blanchard et al. (1990)) focus on these public spending commitments by estimating future expenditure trends (see also Hagemann and Nicoletti (1989)).

The distinct risk features of the various implicit or explicit tax and expenditure claims need to be recognised. To illustrate, governments typically have much more leeway in reducing implicit expenditure commitments associated with subsidy schemes than in defaulting on their public debt. In this connection, the implicit tax claim on institutional investors has different characteristics from the stock of public debt. First, the tax claim depends on the future effective income tax rate on pension benefits. For example, the government suffers a windfall loss if it reduces the personal income tax rate or if retirees emigrate. Second, the return on the tax claim corresponds to that on the assets of the pension funds. This return can differ from the return on public debt. In particular, the return on pension funds that invest a large share of their capital in equities may well significantly exceed the return on government debt. Accordingly, the return on the tax claim of the Governments in the United States and the United Kingdom may exceed that of the Dutch Government because Dutch pension funds invest a relatively small share of their capital in equities.

\section{Estimating Tax Claims on Pension Funds}

Table 2 contains data on the assets of private and public pension funds in several countries. ${ }^{6}$ It appears that the size of funded pension schemes (relative to GDP)

\footnotetext{
${ }^{4}$ When the population ages, large funded supplementary pension schemes benefit the public finances on two accounts. First, they yield a broader base for income and consumption taxes. Second, they tend to imply lower public spending on pay-as-you-go public pensions. High private pensions are also likeiy to reduce the demand for other types of public spending, such as health and social security spending.

${ }_{5}$ The public sector bears a substantial share of the costs of environmental damage because 'the polluter pays' principle cannot be applied in all circumstances.

${ }^{6}$ Methods for the valuation of assets in pension funds differ across countries, in part due to differences in regulatory regimes. These differences complicate an international comparison of the size of pension funds and life assurance companies. In particular, the assets in pension and life assurance funds in countries that adopt conservative valuation methods may be underestimated.
} 
differs substantially across countries. Funded pension schemes play a major role in the Netherlands, the United Kingdom and the United States. Moreover, the pension assets in these countries show considerable growth. Pension funds are not well developed in Germany, in part because the tax treatment of contributions to pension funds is less favourable than in other countries. However, employers' contributions to book reserves are not taxed. Hence, companies in Germany (and also in Austria) rely heavily on book reserves as these reserves constitute a cheap form of financing. In France, pension funds are small because pay-as-you-go schemes provide the bulk of pension provisions.

TABLE 2

Public Debt, Pension Funds and Life Insurance Reserves in Selected OECD Countries, 1984 and 1989

Percentage of GDP

\begin{tabular}{|c|c|c|c|c|c|c|}
\hline & $\begin{array}{c}\text { Supplementary } \\
\text { pension } \\
\text { funds }^{a}\end{array}$ & $\begin{array}{l}\text { Life } \\
\text { insurance } \\
\text { reserves }\end{array}$ & $\begin{array}{l}\text { Gross } \\
\text { public } \\
\text { debt }\end{array}$ & $\begin{array}{l}\text { Tax claim } \\
\text { on pension } \\
\text { funds }\end{array}$ & $\begin{array}{l}\text { Tax claim } \\
\text { on life } \\
\text { insurance } \\
\text { reserves }\end{array}$ & $\begin{array}{c}\text { Public debt } \\
\text { adjusted } \\
\text { for tax } \\
\text { claims }\end{array}$ \\
\hline \multicolumn{7}{|l|}{1984} \\
\hline United States & 32 & 16 & 46 & 6 & 3 & 36 \\
\hline Japan & 12 & 14 & 68 & 2 & 3 & 63 \\
\hline United Kingdom & 40 & n.a. & 55 & 8 & n.a. & n.a. \\
\hline Netherlands & 62 & 19 & 66 & 12 & 4 & 50 \\
\hline Germany & 5 & $22^{\mathrm{c}}$ & 42 & 0 & 5 & 37 \\
\hline France & 2 & 2 & 44 & 0 & 0 & 43 \\
\hline \multicolumn{7}{|l|}{1989} \\
\hline United States & 46 & 16 & 54 & 9 & 3 & 42 \\
\hline Japan & 19 & 25 & 69 & 4 & 5 & 60 \\
\hline United Kingdom & 58 & 49 & 39 & 12 & 10 & 17 \\
\hline Netherlands & 81 & 26 & 81 & 16 & 5 & 59 \\
\hline Germany & 6 & $26^{\mathrm{c}}$ & 43 & 0 & 5 & 38 \\
\hline France & 2 & 9 & 47 & 0 & 2 & 45 \\
\hline
\end{tabular}

${ }^{\mathrm{a}}$ Includes funds in both the public and the private sector.

${ }^{b}$ Based on the hypothesis that the average tax rate on supplementary pension benefits (except those paid by German pension funds) is 20 per cent.

${ }^{c}$ Includes book reserves in non-financial corporations.

Source: OECD, Economic Outlook, December 1990; OECD Financial Accounts, Part 2; Intersec Research Corp., 1990.

Table 2 adjusts the public debt figures for the tax claim on funded pension schemes. The calculation is based on the assumption that all countries tax supplementary pensions at an effective rate of, on average, 20 per cent. Clearly this 


\section{Fiscal Studies}

is a very crude assumption because the respective countries differ with respect to tax exemptions for pension benefits, tax rates and so on. Therefore, the tax rate of 20 per cent is only a working hypothesis to gain a first impression about the order of magnitude of the implicit tax claims. Further research on the effective income tax rates in the various countries is desirable. The effective rate should be based on expectations concerning future average tax rates on pension benefits. It is also affected by the share of private pension benefits that escapes domestic tax because the pension benefits are paid out to retirees residing abroad.

Our estimates suggest that the four countries with the highest public debt in 1984 featured the highest tax claim on funded pension benefits. The already low public debt figure of the United Kingdom in 1989 becomes by far the lowest after the correction for the tax claim. Although the Netherlands experienced the most substantial increase in the tax claim (as a percentage of GDP) between 1984 and 1989 , this country still shows the largest growth of the adjusted public debt figures.

Table 2 also presents the assets of life assurance companies. A tax claim rests on these assets too, because governments tax a substantial share of the benefits that are paid out of these assets. The United Kingdom and the Netherlands - the countries with the largest ratios of pension funds to GDP - also feature substantial life assurance assets.

In order to derive a tentative estimate for the fiscal claim on life assurance companies, Table 2 further corrects the public debt figures for the tax claim on life assurance assets. It adopts the assumption that the effective tax claim on future life assurance benefits is also 20 per cent. Clearly, also this is a very crude estimate for the expected future tax rates in different countries. Compared with the tax rate on benefits from pension funds, the tax rate on benefits from life assurance companies may be lower because a smaller share of life assurance contributions benefits from a cash-flow tax treatment. However, life assurance benefits tend to accrue to higher-income retirees, which raises the effective tax rate.

Table 3 combines the results of the adjustments performed in Tables 1 and 2 to arrive at internationally comparable data on public debt that account for both the funding of public pensions and the tax claim on institutional investors. The difference between the regular and adjusted public debt figures turns out to be largest for the Netherlands, namely almost 50 per cent of GDP. The corrections for Germany and France appear relatively small.

IV. TWO CONSUMPTION TAX TREATMENTS OF PENSION SAVING

This section examines various considerations that play a role in choosing between the two alternative consumption tax treatments of pensions, namely the cash-flow and prepayment systems. These considerations may be especially relevant for 
TABLE 3

Adjustments of Gross Public Debt (PD) for Pension Assets of

Public Employees (PPA), Social Security Assets (SSA), Tax

Claim on Assets of Private Pensions (FCP) and Tax Claim on

Life Insurance Companies (FCA) in Selected OECD Countries, 1989

Percentage of GDP

\begin{tabular}{l|cccrrc}
\hline & $P D$ & $F C P$ & $P P A^{\mathrm{a}}$ & $F C A$ & $S S A$ & Adjusted $P D$ \\
\hline United States & 54 & 9 & 14 & 3 & 3 & 25 \\
Japan & 69 & 4 & 10 & 5 & 18 & 32 \\
United Kingdom & 39 & 12 & 14 & 10 & 0 & 3 \\
Netherlands & 81 & 16 & 27 & 5 & 0 & 33 \\
Germany & 43 & 0 & 0 & 5 & 0 & 38 \\
France & 47 & 0 & 0 & 2 & 0 & 45 \\
\hline
\end{tabular}

a Adjusted for tax claim, which is included in FCP.

Source: Tables 1 and 2.

Eastern European economies that are setting up funded private pension schemes. They are also relevant for countries that are considering changing the tax treatment of pension saving. ${ }^{7}$

\section{Intertemporal Tax Arbitrage}

Under the cash-flow tax, individuals can arbitrage across different (expected) tax rates during their lifetimes. This can be important because marginal tax rates during the working life often exceed (expected) marginal tax rates during retirement, as marginal personal income tax rates tend to increase with income. Social security taxes may strengthen this effect. While pension benefits typically are not liable to social security taxes, pension premiums are generally not included in the base for social security taxes. Accordingly, by postponing their consumption until retirement through pension saving, households can take advantage of lower tax rates during retirement. In fact, the effective tax rate on the return on pension saving is negative and pension saving is subsidised if marginal tax rates when working exceed the corresponding rates when retired. ${ }^{8}$ Under the prepayment method, in contrast,

\footnotetext{
${ }^{7}$ By levying a one-off wealth tax on pension funds, countries with mature pension systems can alleviate the transitional problems associated with moving from the cash-flow to the prepayment system.

${ }^{8}$ In examining the incentives to shift consumption through pension saving, one may also have to explore how effective marginal tax rates during the working life and retirement period are affected by income-dependent prices and public transfers or own contributions that depend on income. There are also tax arbitrage opportunities if individuals expect the government to reduce the income tax rate or the tax rates on consumption (such as VAT) before or during their retirement.
} 


\section{Fiscal Studies}

households cannot arbitrage across the different marginal rates, and the effective tax rate on the return is always zero.

The intertemporal tax arbitrage under the cash-flow system distorts the intertemporal allocation of consumption by providing an artificial incentive to shift consumption to periods when tax rates are expected to be low and saving to periods with high tax rates. The cash-flow treatment, however, allows individuals who earn their income mainly at the beginning of their life to spread their taxable income more evenly over their whole lifetime. This yields a more equitable tax system if one considers lifetime income to be a more equitable tax base than annual income as marginal tax rates are based on lifetime rather than annual income (see, for example, Kay (1990)).

\section{International Tax Arbitrage}

In contrast to the prepayment method, the cash-flow system allows tax arbitrage across tax rates in different countries. In particular, workers in high-tax countries can benefit from low personal tax rates in foreign countries by retiring abroad. In fact, retirees may establish residence in countries with low tax rates but may continue to benefit from high public spending in high-tax countries as they spend most of their time in these latter countries. These arbitrage activities harm high-tax countries and may result in downward pressure on income tax rates as the international mobility of retirees increases in particular regions, such as the European Community. They may also put pressure on countries to harmonise their tax structures. To illustrate, if some countries rely primarily on labour taxes while others adopt mainly consumption taxes, agents may arbitrage across these tax systems by working in the consumption-tax country and retiring to the country that relies on labour taxes. EC countries may also want to anticipate the growing mobility of labour by moving toward 'benefit' taxes, which establish a closer link between taxes paid and public benefits received.

\section{Risk Features}

Under the cash-flow tax, the government in effect buys a share in the pension funds. Accordingly, the government shares in the investment risk of the pension funds because the average rate of return on the government's share equals the average rate of return on the investments of the pension fund. Under the prepayment version of the consumption tax, in contrast, the government has a lower stock of public debt and, therefore, earns a return equal to that on government bonds. In countries where the return on pension funds exceeds that on government bonds, therefore, the prepayment method yields less discounted tax revenue - at least if the tax rate during retirement does not differ from that during the working period. In effect, the cash-flow tax levies a tax on rents (that is, the 'interest' premium earned by pension 
funds). Accordingly, the government may find a cash-flow tax more attractive than the prepayment method if it has confidence in the investment policy of the pension funds and at the same time expects to be able to borrow at low rates. If the pension funds invest in government paper, however, the government in effect invests in itself under a cash-flow tax. Under these circumstances, the prepayment system may save on transaction costs. In this connection, the prepayment system may be interpreted as interfering with the free international movement of capital because the government in effect forces pension funds to invest in government paper. Furthermore, the cash-flow system may enhance the credibility of the government's commitment to sound fiscal policies because the government is more vulnerable to changes in the risk premium on its debt instruments.

\section{Imperfect Capital Markets}

Compared with the situation under the prepayment system, under the cash-flow system the government in effect provides a loan to the private sector. This may enhance welfare if the government can borrow at lower rates than the private sector. By relieving liquidity constraints, the cash-flow tax may also yield lower national saving compared with the prepayment system. The reason for this is that private saving will not rise sufficiently to offset the rising financial deficit of the public sector. ${ }^{9}$ Indeed, the cash flow of the government becomes a better indicator of fiscal policy if households face liquidity constraints. The analysis of Hubbard and Judd (1986) suggests that liquidity constraints may exert a powerful impact on the effects of policy on private consumption.

\section{Imperfect Political Process and Budget Discipline}

The cash-flow tax forces the government to borrow more on capital markets. The resulting higher stock of public debt may strengthen budget discipline when pension funds are being built up. This may benefit future generations: larger revenues from a broader tax base are not offset by higher interest spending on a larger stock of public debt. In an ageing society, the cash-flow tax has the advantage that a broader tax base coincides with large expenditure needs.

Whether the cash-flow tax produces higher nati onal saving than the prepayment system depends on the relative importance of 'imperfections' in the private and public sectors. If private capital markets function perfectly and households do not face liquidity constraints and anticipate future taxes but the government fails to take

\footnotetext{
${ }^{9}$ This illustrates that tax incentives for private saving that defer taxes may not be successful in raising national saving. This is especially so if the combination of these tax incentives with the deductibility of mortgage interest provides opportunities for tax arbitrage. See also Stiglitz (1985). National saving may also fall if househoids feature short time horizons so that they heavily discount future tax payments on retirement benefits.
} 


\section{Fiscal Studies}

into account its claim on private pension funds or suffers from constraints on its borrowing, the cash-flow tax is likely to yield the highest level of national saving. However, if the government incorporates this claim in its decision-making but the private sector features short horizons or faces liquidity constraints, the prepayment method may well produce the highest national saving.

In this connection, the government may face difficulties in borrowing large amounts because of fears that the government will inflate its nominal debt away. This will be especially so if pension and life assurance funds are well hedged against inflation. In that case, unanticipated inflation will improve public wealth as the erosion of nominal public debt exceeds the decline in the real value of the fiscal claim on pension funds. If the government faces these credibility constraints, it may want to change the composition of its assets and liabilities by opting for the prepayment system as a device to increase the credibility of its anti-inflation commitment.

\section{Changes in Tax Rates and Windfall Gains and Losses}

During the period when pension funds are built up, a cash-flow tax yields a smaller income tax base than the prepayment system does. After the pension funds have matured, however, the income tax base is broader (see Section III). The government benefits from this if personal income tax rates are rising over time. ${ }^{10}$ In that case, pension benefits are taxed at higher rates than those at which the premiums corresponding to these benefits have been deducted. Intuitively, the government expropriates part of the pension funds, if it raises personal income tax rates on pension benefits. Accordingly, the public sector benefits from a windfall gain at the expense of those who receive pension benefits. ${ }^{11}$ Similarly, the government suffers a windfall loss if it reduces personal income tax rates on pension benefits. The government can avoid this windfall loss by levying a one-off wealth tax on pension funds.

\section{Insurance against Unexpected Shocks with a Broader Tax Base}

A cash-flow tax seems to provide better insurance against unexpected shocks in an ageing society with mature pension funds because the government has a broader tax base at its disposal. Under a prepayment system, pension premiums are included in the tax base. Under the alternative cash-flow version, however, it is pension benefits that are taxed. In a mature pension fund, benefits exceed premiums - especially in

\footnotetext{
${ }^{10}$ Unless falling indirect consumption tax rates accompany rising personal income taxes.

${ }^{11}$ An unexpected increase in indirect consumption taxes amounts to the expropriation of a part of all assets, including non-pension assets. See Auerbach and Kotlikoff (1987).
} 
an ageing society. ${ }^{12}$ Hence, compared with the prepayment system, the cash-flow tax yields a broader tax base, and smaller changes in tax rate are required to collect a given amount of tax revenue. This may reduce the deadweight losses and uncertainties associated with the tax system.

\section{Stabilisation Aspects}

The two systems differ in how changes in interest rates are transmitted to the economy. Compared with the situation under the prepayment system, rising interest rates produce a larger improvement in the short-run cash flow of the pension funds and a larger deterioration of the cash flow of the public sector ${ }^{13}$ under the cash-flow tax. The short-run effect on aggregate demand depends on the saving ratios of the pension funds and the public sector. If the pension funds feature a high saving ratio and if the public and private sectors operate under cash-flow constraints, ${ }^{14}$ rising interest rates are likely to depress aggregate demand the most under the cash-flow tax.

\section{CONCLUSIONS}

This paper has contributed to the development of indicators measuring the intertemporal impact of fiscal policy. It has illustrated that conventional data on public debt and public deficits need to be supplemented by information on the structure of the tax and expenditure systems in order to correctly assess the sustainability of fiscal policy and the effect of fiscal policy on intergenerational equity. This supplementary information is especially important in economies that are in transition. Moreover, as financial liberalisation proceeds and markets develop, measures of fiscal policy that take account of the microeconomic aspects of the structure of the tax and expenditure systems gain in importance.

This paper has focused on how data on public debt and public wealth are affected both by the financing arrangements for social security pensions and supplementary pensions of public employees and by the interaction of the tax treatment of pension saving and the importance of pension and life assurance funds in the private sector. In particular, governments that establish funds to meet their pension obligations may be in a better financial position than those that rely on pay-as-you-go systems. Furthermore, governments in countries that combine high levels of pension saving with high income and consumption tax rates accumulate assets of an implicit kind, namely a tax claim on pension assets. While public debt may rise as the cash-flow measure of the public deficit records substantial deficits, public wealth may

\footnotetext{
${ }^{12}$ In fact, pension benefits (consumption) exceeding pension premiums (saving) is a condition for the dynamic efficiency of funded schemes. See, e.g., Abel et al. (1989).

${ }^{13}$ Assuming that the public sector is a net debtor.

${ }^{14}$ This will be the case if the government has set targets for its financial balance.
} 


\section{Fiscal Studies}

nevertheless increase. Although more research is required, the empirical estimates presented in this paper suggest that the assets in public pension funds as well as the implicit tax claims on pension assets may be quite large relative to the level of public debt. Moreover, changes in these assets may importantly affect conventional measures of public deficits.

Developing indicators that measure changes in these public assets may help to identify unsustainable policies that erode public wealth, for example by reducing implicit tax claims. These considerations are especially important in evaluating tax reforms. For example, by substituting a wage tax for a sales tax, the government reduces its implicit tax claim on private assets. This has important implications for governments that are considering changing the tax treatment of pensions from the cash-flow to the prepayment system. Such a tax reform would be expansionary in the short run if it were revenue-neutral, as the currently living generations would gain at the expense of future generations. To avoid this, the government must accompany this tax reform by the retirement of public debt.

This paper has also examined several considerations that are relevant in deciding how to tax pension saving. The discussion suggested that the cash-flow tax is likely to require international co-ordination to avoid tax arbitrage across tax rates in different countries as retirees become more mobile internationally. Moreover, to prevent financial liberalisation from undermining the income tax through tax arbitrage between pension saving and other types of saving, countries may also have to co-operate to effectively tax capital income on pension saving.

\section{REFERENCES}

Abel, A. B., Mankiw, N. G., Summers, L. H. and Zeckhauser, R. J. (1989), 'Assessing dynamic efficiency: theory and evidence', Review of Economic Studies, vol. 56, pp. 1-20.

Auerbach, A. J. and Kotlikoff, L. J. (1987), Dynamic Fiscal Policy, Cambridge: Cambridge University Press.

Blanchard, O. J., Chouraqui, J., Hagemann, R. P. and Sartor, N. (1990), 'The sustainability of fiscal policy: new answers to an old question', OECD Economic Studies, no. 15, pp. 7-36.

Blejer, M. and Cheasty, A. (1991), 'The measurement of fiscal deficits: analytical and methodological issues', Journal of Economic Literature, vol. 29, pp. 1644-78.

Hagemann, R. P. and Nicoletti, G. (1989), 'Population ageing: economic effects and some policy implications for financing public pensions', OECD Economic Studies, no. 12.

Heller, P., Hemming, R. and Konhert, P. W. (1986), 'Aging and social expenditure in the major industrial countries, 1980-2025', IMF Occasional Paper, no. 47, September.

Hubbard, R. G. and Judd, K. L. (1986), 'Liquidity constraints, fiscal policy, and consumption', Brookings Papers on Economic Activity, pp. 1-59.

Kay, J. (1990), 'Consumption and income taxation: horizontal equity and life cycle issues', in M. Rose (ed.), Heidelberg Congress on Taxing Consumption, Heidelberg: Springer-Verlag.

Munnell, A. H. and Ernsberger, C. N. (1989), 'Public pension surpluses and national saving: foreign experience', New England Economic Review, March/April, pp. 16-38.

Stiglitz, J. (1985), 'The general theory of tax avoidance', National Tax Journal, vol. 38, pp. 325-37. van Loo, P. D. (1990), 'De beleggingen van pensioenfondsen', in C. Petersen (ed.), Pensioenen, Uitkeringen, Financiering en Beleggingen, Leiden. 